US Army Corps

of Engineers $s_{\circledast}$

Engineer Research and

Development Center

\title{
Peat and Organic Soil Characterization During Seasonal Mobility Testing
}

Susan Frankenstein, Lynette Barna, Bruce Elder, Sally Shoop,

August 2020

Mike Parker, Michelle Michaels, and Mary Feyrer 
The U.S. Army Engineer Research and Development Center (ERDC) solves the nation's toughest engineering and environmental challenges. ERDC develops innovative solutions in civil and military engineering, geospatial sciences, water resources, and environmental sciences for the Army, the Department of Defense, civilian agencies, and our nation's public good. Find out more at www.erdc.usace.army.mil.

To search for other technical reports published by ERDC, visit the ERDC online library at https://erdclibrary.on.worldcat.org/discovery. 


\section{Peat and Organic Soil Characterization During Seasonal Mobility Testing}

Susan Frankenstein, Lynette Barna, Bruce Elder, Sally Shoop, Mike Parker, Michelle Michaels, and Mary Feyrer

Cold Regions Research Laboratory

U.S. Army Engineer Research and Development Center

72 Lyme Road

Hanover, NH 03755

Final report

Approved for public release; distribution is unlimited.

Prepared for Assistant Secretary for Army Acquisitions, Logistics \& Technology Washington, DC 20314

Under Program Element 62784, Project Number AT40, Task Number 48 


\section{Preface}

This study was conducted for the Assistant Secretary of the Army, Acquisition, Logistics and Technology under Program Element 62784, Project Number AT40, and Task Number 48. The technical monitor was John Rushing.

The work was performed by the Terrestrial and Cryospheric Sciences Branch and by the Force Projection and Sustainment Branch of the Research and Engineering Division, U.S. Army Engineer Research and Development Center, Cold Regions Research and Engineering Laboratory (ERDC-CRREL).

At the time of publication, Dr. John Weatherly was Chief, Terrestrial and Cryospheric Sciences Branch; Mr. Justin Putnam was Acting Chief, Force Projection and Sustainment Branch; Mr. Jimmy Horne was Division Chief and Dr. Bert Davis, was the Technical Director for Geospatial Research and Engineering/Military Engineering. The Deputy Director of ERDCCRREL was Mr. David B. Ringelberg, and the Director was Dr. Joseph L. Corriveau.

This paper was originally published as a proceeding of the ISTVS 15th European-African Regional Conference, Prague, Czech Republic, September 9-11, 2019 and funded under the Entry and Sustainment in Complex Contested Environments Project (Mobility in Peat and Northern Soils project under the 6.2 T40 ASTMIS).

The Commander of ERDC was COL Teresa A. Schlosser and the Director was Dr. David W. Pittman. 


\title{
Peat and Organic Soil Characterization During Seasonal Mobility Testing
}

\begin{abstract}
Renewed interest in cross country mobility due to the current global political climate, as well as greater accessibility to northern regions due to climate change, has led to identification of deficiencies in current mobility modeling capabilities on peat and organic soils for both tracked and wheeled vehicles. As a result, field tests at two locations were initiated in the Winter of 2019 to quantify vehicle, soil, and other environmental characteristics. Measured parameters include, but are not limited to, soil moisture and temperature profiles from the surface to $50 \mathrm{~cm}$ depth; full weather forcing variables; snow depth; soil characterization including grain size distribution, density, porosity, organic content, and inherent strength factors; vegetation type and density including root structure; soil strength; vehicle traction, resistance, and sinkage. Tests are designed to capture seasonal conditions to include frozen soil, early thaw, and mid-summer. Preliminary analysis of the soil and environmental characteristics are presented in this paper.
\end{abstract}

Keywords: Peat, Field Experiments, Vehicle Mobility, Frozen Ground, Organic

\section{Introduction}

Peat and highly organic terrain, as well as gravelly soils, cover large portions of the northern climate zones. Recently, interest in these areas has increased. Vehicles have great difficulty traversing these terrain types except under certain conditions. Therefore, there is a great need to better understand vehicle and terrain interactions in these regions to better predict vehicle mobility. Determining seasonal impacts is crucial for these areas as terrain that may be impassible during warmer months can become trafficable when frozen.

Previous studies by Wong et al. $(1979,1982)$ focus on unfrozen peat and muskeg for a single condition, and does not look at the effect of changing moisture conditions or the effect of freezing or thawing. Other studies conducted on multiple peat and muskeg types (Radford and Rush 1961) report general observations but do not make any correlations between vehicle mobility and peat and muskeg type. Shoop (1995) and Richmond et al. (1995) developed an equation to represent the breakthrough limits for a frozen peat layer over a soft substrate. They do not provide sinkage, motion resistance, or tractive force values needed to quantify vehicle mobility on this soil type.

New experimental data sets are required to create more accurate vehicle mobility predictions across multiple seasons for highly organic terrains. Experiments should focus on collecting vehicle mobility and soils characterization data when the soil is frozen, thawed, wet, dry, and with a thin snow cover to see how mobility is affected by each of these ground states. Experiments should be conducted using both tracked and wheeled vehicles. Vehicle measurements should include drawbar pull, motion resistance, sinkage, wheel speed, vehicle speed, and other key parameters. These measurements should be correlated with vegetation (above and below ground) and soil temperature, moisture, density, shear strength, California bearing ratio, and other measurable parameters.

The authors are solely responsible for the content of this technical presentation. The technical presentation does not necessarily reflect the official position of the International Society for Terrain Vehicle Systems (ISTVS), and its printing and distribution does not constitute an endorsement of views which may be expressed. 
In this paper the preliminary soil characterization from two test sites are presented. The first location is the Camp Ethan Allen Training Site (CEATS) in Jericho, VT and the second is an abandoned farm next to an emerging wetland in Grantham, NH. Terrain characterization was conducted both in winter and in spring in coordination with vehicle testing discussed by Parker et al. (2019 this issue).

\section{Test Sites}

\subsection{Camp Ethan Allen Training Site (CEATS)}

CEATS is an 11,000-acre reserve located in northern Vermont about 1.5 hour drive from ERDC-CRREL (Cold Regions Research and Environmental Laboratory) and is home to the Army Mountain Warfare School (Fig. 1a). Based on the U.S. Department of Agriculture (USDA) USCS (Unified Soil Classification System) soil map and the CEATS map, we selected an abandoned airstrip on the southern border that is flat and level, receives little traffic from the National Guard, and is easily accessible for vehicle testing (Fig. 1a). The soil type here is silty sand (SM) and highly plastic silt $(\mathrm{MH})$ as shown in Fig. 1b. The surface is covered with grass which is cut on a regular basis. The upper 5-8 $\mathrm{cm}$ is high in organic matter (Fig. 1d). Vehicle tests were performed moving from west to east.

Combined vehicle and soil characterization tests were conducted on 26 February and 16-17 April 2019. Another test is planned for late August. Conditions at these times represented a frozen soil with a thin snow cover and early thawed soil respectively. Scheduling of the August field campaign is intended to capture a dry ground state. Controlling conditions for field campaigns is difficult. Due to the early arrival of snow in the 2018-2019 winter season a desired frozen, but bare, soil situation was not possible.

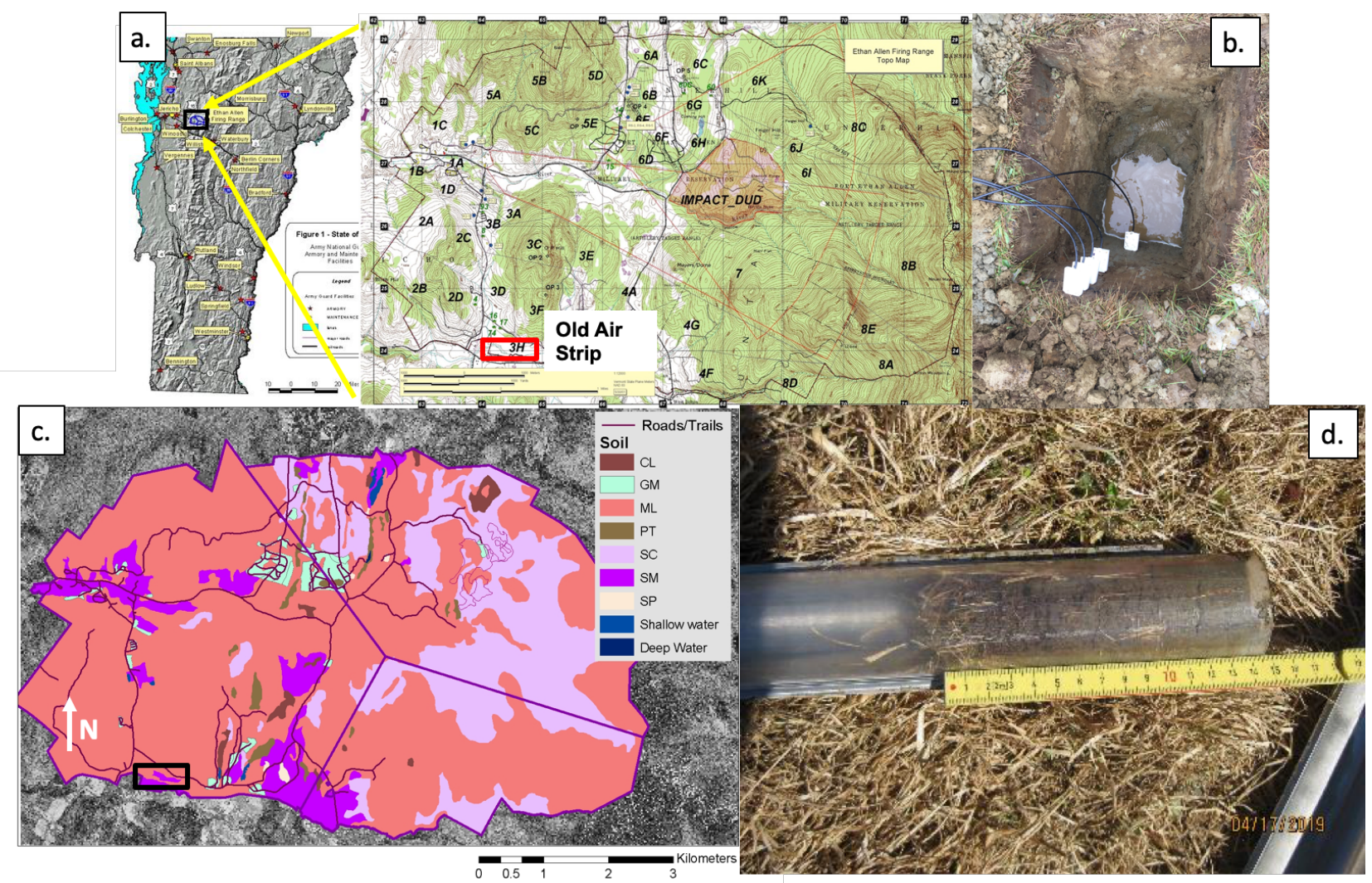

Fig. 1. CEATS. a. location of test site at old air strip, b. installation of soil moisture and temperature probes, c. soil map showing USCS soil types, $d$. soil sample showing top organic layer. 


\subsection{Grantham, NH}

The Grantham, NH site is located at approximately $43.565^{\circ} \mathrm{N}, 72.149^{\circ} \mathrm{W}$ at an abandoned farm (Fig. 2a) that is still mowed once a year if conditions permit. According to the USDA and New Hampshire soil maps, the site consists of mucky silty loam (Sb, Fig. 2b - USCS soil type CH), mucky peat (Gw, Fig. 2b - USCS soil type Pt), and fine sandy loam (Ru Fig. 2b - USCS soil type CL) as shown in the outlined section of Fig. 2b. It is considered an emerging wetland and a small stream flows along the eastern edge of the test lane. The organic soil layer tends to be 9-12 cm as can be seen in Fig. 2c where the organic, heavily rooted layer is at the bottom of the picture. It is much wetter than the CEATS location, especially at the far ends of the vehicle test lanes which ran roughly from north to south on the south side of the barn and south to north on the north side of the barn.

Similar to the CEATS site, snow fell before the ground froze. Unlike CEATS, the snow remained until early April and was too deep to enable winter frozen soil vehicle tests. However, frozen soil characterizations were captured on 22 March 2019. The early Spring thaw scenario was captured on 23 April 2019. Vegetation samples for species identification were taken at this time. Unfortunately, the soil was too weak to perform vehicle tests at this time. Vehicle tests representative of wet conditions were conducted on 4-6 June 2019.

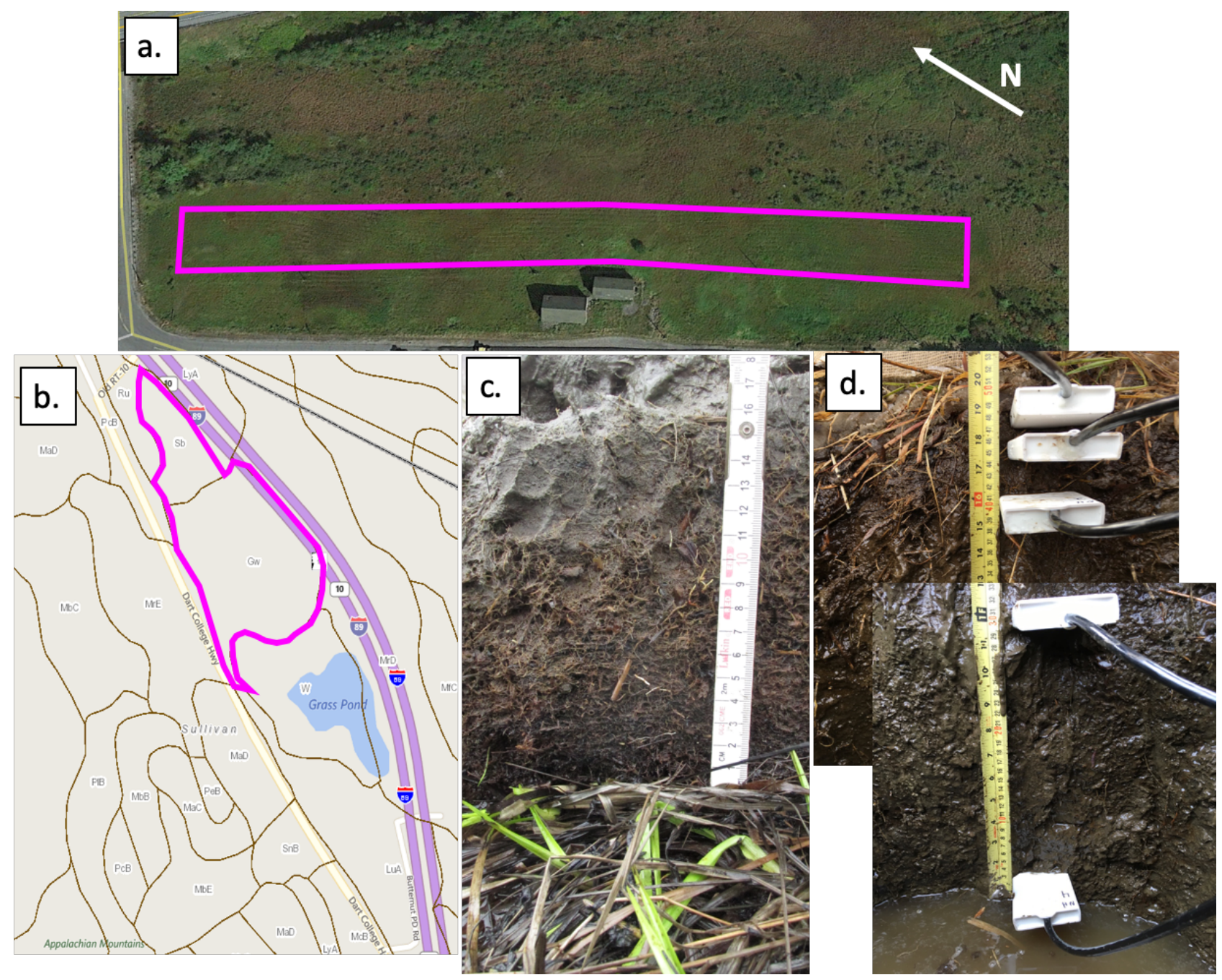

Fig. 2. Grantham, NH site. a. vehicle test lane, b. soil taxonomy map, c. soil profile, $d$. placement of soil temperature and moisture probes. 


\section{Vehicles}

The two test vehicles consisted of a light wheeled and a light tracked. Specifically, a HMMWV (High Mobility Multipurpose Wheeled Vehicle) and SUSV (Small Unit Support Vehicle) were used and are shown in Fig. 3 with some of the instrumentation used to measure pertinent mobility parameters. Three tests were performed each time: a hard surface rolling resistance on pavement, drawbar pull test for net traction, and a gross motion resistance test. More details on test set-up and results can be found in Parker et al. (2019 this issue).

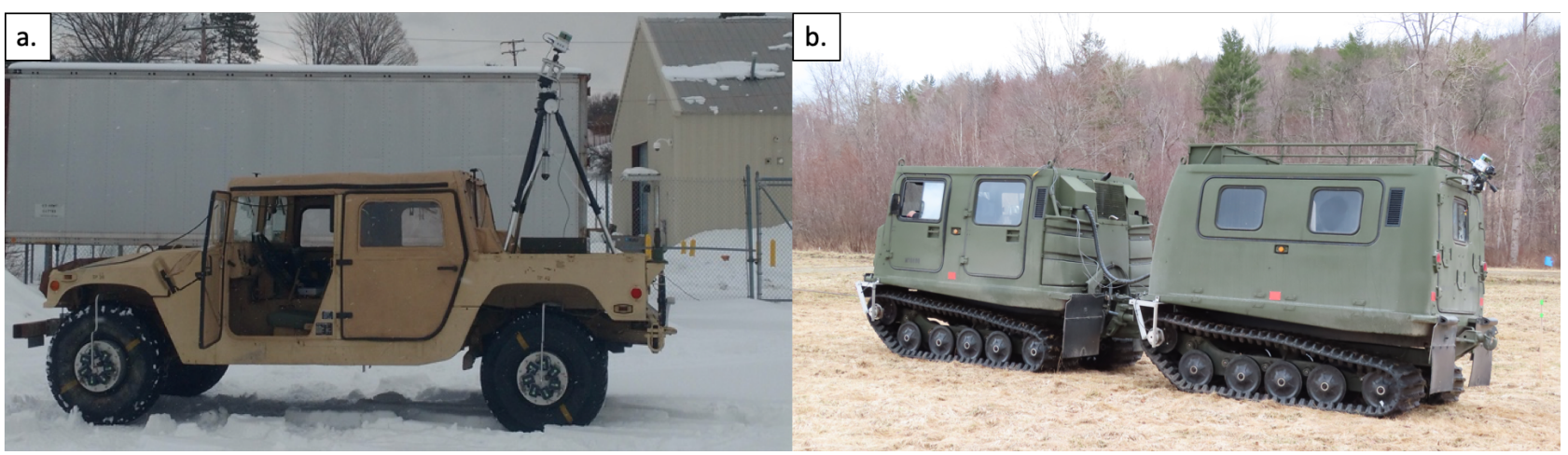

Fig. 3. Test vehicles. a. instrumented HMMWV, b. instrumented SUSV

\section{Measurements}

\subsection{Strength-Dynamic Cone Penetrometer (DCP)}

Webster et al. (1992) provides a detailed description of the DCP. This device measures penetration into the soil of a $5 / 8$ in $(16 \mathrm{~mm})$ steel rod with a $60^{\circ}$ cone on the end for a given number of drops of a known mass. The mass contacts an anvil and acts like a large slide hammer. Penetration depths at the two sites ranged from $500-900 \mathrm{~mm}$. Since the height of the mass drop is known, the measurements can be converted into a strength measurement. Either a $7.99 \mathrm{~kg}$ or $4.59 \mathrm{~kg}$ mass is used depending on the soil type. The smaller mass is typically used in weaker, cohesive soils, while the heavier mass is used in high-strength soils. For this study we used the light weight at both sites. The equation used to convert DCP (mm/blow) values to the California Bearing Ratio (CBR) is for clays and non-clay soils respectively (Air Force, 2002)

$$
\begin{aligned}
& C B R=\frac{1}{(0.017019[2 D C P])^{2}} \\
& C B R=\frac{292}{[2 D C P]^{1.12}}
\end{aligned}
$$

The factor ' 2 ' is needed to account for the fact that the lighter weight was used.

\subsection{Strength - Cone Penetrometer}

Cone penetrometer measurements from 0 to a maximum of 18 inches were taken at both sites. The cone penetrometer is a testing device used to expediently determine the trafficability of soils (HQ Army and Air Force, 1994). It consists of a steel rod $16 \mathrm{~mm}(5 / 8 \mathrm{in})$ in diameter and $483 \mathrm{~mm}$ (19 in) long, tipped with a $30^{\circ}$ cone having a $322 \mathrm{~mm}^{2}\left(0.5 \mathrm{in}^{2}\right)$ base. This tip size is suitable for fine-grained soils. To operate the instrument, the rod is set vertically on the surface of the soil and, with a steady downward force, the tip is pushed into the soil. The maximum measurement depth is $457 \mathrm{~mm}$ (18) 
in). Strength readings (cone index, CI, in psi $(\mathrm{kPa})$ ) are recorded every $25.4 \mathrm{~mm}(1 \mathrm{in})$. A sensor mounted at the top of the probe with a $30^{\circ}$ field of view is used to measure the tip depth. In areas with high vegetation such as Grantham, a rectangular metal plate with a hole in the center is used to remove surface interference. Without this, depth errors are incurred and the probe stops functioning. Depth errors can also happen if the penetrometer tip moves too quickly through the soil. This often occurs when moving from a firmer to softer layer. This was a problem at the Grantham site due to the high root density of the upper layer requiring more pressure to push through than the softer layer underneath.

The data were processed by calculating the average cone index over the top $152 \mathrm{~mm}(6 \mathrm{in})$ and $127 \mathrm{~mm}(5 \mathrm{in})$ increments. The first depth increment is used by mobility models such as NRMM (NATO Reference Mobility Model) while the second corresponds to the TDR probe length used to measure soil moisture (Sec. 4.5). The top reading used was the first non-zero reading as the zero values represent above ground vegetation. At Grantham, this could be as much as $76 \mathrm{~mm}$. To compare with the other soil strength measurements, the CBR was estimated using the following exponential relationship based on data collected using a small-aperture CBR test and laboratory data collected at ERDC-CRREL (Shoop et al., 2008)

$$
C B R=a C I^{b}
$$

The coefficients $a$ and $b$ are USCS soil type dependent and are given in Table 1 for the soils found at CEATS and Grantham. Note that this type of information is not available specifically for organic or peat soil types.

Table 1. Coefficients used to convert cone index values to CBR measurements.

\begin{tabular}{|c|c|c|}
\hline USCS Soil Type & $a$ & $b$ \\
\hline SM & 1.1392 & 0.4896 \\
\hline MH & 0.082 & 0.7174 \\
\hline CL & 0.1266 & 0.6986 \\
\hline CH & 0.1264 & 0.6979 \\
\hline
\end{tabular}

\subsection{Strength-Clegg Impact Soil Tester}

The Clegg soil impact tester is commonly used for quality control to verify the materials compacted during highway and road construction (Affleck et al., 2008). The test device is portable, easy-to-use, and nondestructive. It consists of a steel tube housing that encloses an impact hammer dropped from a specific height. There are several mass sizes available $(0.5,2.25,4.5$, and $20 \mathrm{~kg}[1.1,5,10,44 \mathrm{lbs}])$ with the standard mass being $4.5 \mathrm{~kg}$ (10 lbs). For this study the $0.5 \mathrm{~kg}$, $2.25 \mathrm{~kg}$, and $4.5 \mathrm{~kg}$ Clegg testers were used. The deceleration of the mass into the soil surface is determined by an accelerometer and reported as an impact value (IV). A relationship, based on testing results of a range of soil types, is used to estimate the soil CBR from the IV. The operating procedure is to set the device on a level location and hold it in place by standing on the flanges at the base of the tube. The hammer is lifted and dropped four times, with increasing readings after each drop. According to the user manual, any imperfections in the upper layer should be smoothed out with the first two drops, and readings should stabilize with the third and fourth readings (SDi, 2000). The fourth IV reading is used to estimate the soil CBR. For the $0.5 \mathrm{~kg}$ (Affleck et al., 2008), $2.25 \mathrm{~kg}$ Clegg (Wieder et al., 2018), and $4.5 \mathrm{~kg}$ Clegg (Clegg, 1986) the equations are respectively

$$
\begin{aligned}
& C B R=0.0121\left[4^{\text {th }} \mathrm{IV}\right]^{2}+0.1005\left[4^{\text {th }} \mathrm{IV}\right] \\
& C B R=\exp \left(\frac{10\left[4^{\text {th }} \mathrm{IV}\right]}{79.523}\right) \\
& C B R=0.24\left[4^{\text {th }} \mathrm{IV}\right]^{2}
\end{aligned}
$$




\subsection{In-situ Density - eGauge}

Near-surface in-situ density was measured at CEATS on 16-17 April 2019 and at Grantham on 22 March and 4-6 June 2019 using the Troxler Model 4590 Surface Density Gauge (eGauge). In conjunction with density, moisture readings were taken with the Troxler Model 6760 Moisture Probe. Density measurements are taken at 2 in $(5 \mathrm{~cm})$ intervals from $2-8$ in $(5-20 \mathrm{~cm})$. Probe. Between the two instruments dry density, wet density, mass of water, and gravimetric water content are measured. The measurements were performed following the ASTM method D8167 (2018) and eGauge manual of operation (Troxler, 2015).

The eGauge operates for a material (dry) density range of 70 to $170 \mathrm{lb} / \mathrm{ft}^{3}\left(1100\right.$ to $\left.2700 \mathrm{~kg} / \mathrm{m}^{3}\right)$. However, many of the measurements at Grantham and CEATS sites are outside this range.

\subsection{Surface Soil Moisture}

A FieldScout TDR (time domain reflectometry) 300 was used to measure percent volumetric surface soil moisture using the standard setting. A high clay setting is also available, but is generally not used. Several tine lengths (3.8, 7.6, 12.0, $20.0 \mathrm{~cm}(1.5,3.0,4.8,8.0 \mathrm{in}))$ are available depending on the hardness of the soil and application. The $12.0 \mathrm{~cm}(4.8 \mathrm{in})$ tines were used at both sites since this is closest to the $15 \mathrm{~cm}$ (6 in) depth required by NRMM without incorporating lower layer effects. Measurement accuracy is $0.1 \%$. A minimum of 5 readings were taken at each location from which the average was calculated. These were compared to measurements made with the eGauge as well as the buried moisture probes associated with the meteorological station (see Sec. 4.7). None of the tines could be inserted into the ground on 26 February at CEATS and 22 March at Grantham as the ground was frozen.

\subsection{Vegetation}

At both sites it is impossible to separate the highly organic soils from the surface vegetation and the roots. Taxonomic samples were taken in early spring before new growth occurred at each location in order to identify plant species. These were then taken into a green house where controlled growth and identification, including root structure characterization, is being conducted. Results from this work were not available at the time of publication.

Besides speciation work, plant height, surface density, and root density during vehicle testing were also measured. To do this, a $25 \mathrm{~cm} \times 25 \mathrm{~cm}$ square was randomly tossed on the ground near the soil sampling sites. Even though the soil was snow free during the 16-17 April tests at CEATS, the vegetation was still dormant and so samples were only taken for species identification. Vegetation taxonomic samples were taken at Grantham on 23 April. Vegetation density information was collected during vehicle tests on 4-6 June 2019.

\subsection{Meteorological Forcing and Subsurface Soil Moisture and Temperature}

At both sites, a WeatherHawk 232 Signature Series weather station with external tipping bucket ( $0.254 \mathrm{~mm}$ resolution) and MaxBotix ultrasonic snow depth sensors with $1 \mathrm{~mm}$ resolution (HRXL-MaxSonar-WRS5) were installed. The weather station measures air temperature $\left(10 \mathrm{~K}\right.$ thermistor, $\left.+/-0.5^{\circ} \mathrm{C}\right)$, pressure (Motorola MAP sensor, $1.5 \%$ ), relative humidity (precision bulk-polymer type, $+/-3 \%$ ), wind speed (3-cup anemometer, $0.78 \mathrm{~m} / \mathrm{s}$ threshold), wind direction (vane, $1 \mathrm{~m} / \mathrm{s}$ sensitivity), and incoming solar radiation (silicon pyranometer, $+/-5 \%$ ). Data is collected every 15 seconds and averaged over 15-minute intervals. The weather station, and soil temperature and moisture probes discussed below, were installed at CEATS on 26 November 2018 and at the Grantham site on 18 November 2018.

Along with the above ground sensors, five Campbell Scientific CS655 volumetric water content reflectometer plus temperature probes with $12 \mathrm{~cm}$ long probes ( $+/-3 \%$ accuracy) were buried next to the meteorological station at depths of 2, 5, 10,20, and $50 \mathrm{~cm}$. Data collection frequency and storage is the same as for the weather station. Pits were dug, probes placed, then back-filled leaving the surface as close to pre-installation conditions as possible. Probe placement at CEATS is shown in Fig. $1 \mathrm{~b}$ and at Grantham in Fig. 2d. The total pit depth at Grantham was $70 \mathrm{~cm}$ at which point a hard layer was encountered. The peat thickness here is approximately $9 \mathrm{~cm}$. Almost immediately after installing the sensors, water seeped into the pit on the north side, quickly inundating the pit. The pit depth at CEATS was $100 \mathrm{~cm}$. 
The water table level at that time was $80 \mathrm{~cm}$. The total organic layer thickness described in Section 2.1 is about $5-8 \mathrm{~cm}$ at this location.

\section{Results}

Soil measurements were taken at a minimum of five locations at both CEATS and Grantham. At CEATS, the first test point (TP1) was western most (left side of box in Fig. 1a, 1c) while TP5 was the furthest east. At Grantham, the first test location was located at the southern end of the vehicle test lanes and TP6 was on the north end (Fig 2a). As discussed above, vehicle tests were done both in winter and early spring at CEATS while at Grantham vehicle tests have only been carried in June. Further testing at both sites is planned for August 2019. Soil characterization studies were conducted at Grantham in late winter and early spring without concurrent vehicle testing. The results of the tests will be discussed below. Companion laboratory testing of the soils at both sites is still in progress.

\subsection{Soil Strength}

Soil strength was measured using several different instruments as discussed previously. Fig. 4 shows the cone index profiles at CEATS on 16 April and Grantham on 4 and 6 June. The first thing that can be seen is the inherent scatter in the data. This is not uncommon. The zero values at the soil surface represents the vegetation cover thickness. This is especially noticeable at Grantham. At CEATS the vegetation cover is much thinner due to mowing. Overall, the upper soil at CEATS is stronger than the soil at Grantham. The soil at Grantham is also wetter (Tables 2-4) and except for sands, wetter soils are weaker than drier ones. The organic layer at CEATS is also thinner than at Grantham and so the increase in strength with depth occurs closer to the surface at this location. Another difference between CEATS and Grantham is that the cone index profile at CEATS gradually increases until approximately $10 \mathrm{~cm}$ (Fig. 4a) after which it is fairly uniform. At Grantham it was very hard to get a continuous reading as the roots in the upper organic layer were relatively strong compared to the underlying soil causing instrument errors due to uneven penetration speed. At Grantham measuring locations TP3, TP4, and TP6 a stronger layer exists at about $30 \mathrm{~cm}$. It is expected that soils become denser, and hence stronger, after vehicle passage due to compression. Kersti et al. (2017) found that organic material behaves more elastically than clays and silts and tends to flow laterally rather than be compressed so that this is not necessarily true. This could account for little, or no, difference in soil strength before and after vehicle passage (Fig. $4 \mathrm{~b}$ and $4 \mathrm{c})$.

The number of DCP drops needed to penetrate the soil are shown in Fig. 5 for the two test dates at CEATS and in Fig. 6 for 22 March and 4-6 June at Grantham. Even though the upper surface of the soil was frozen on 26 February, little difference is seen between DCP values at CEATS except for at TP4 and TP5 for the two test dates as can be seen in Fig. 4. TP4 is stronger at depth on 26 February while TP5 is the stronger soil on 16 April. The cause for these differences is unknown.

At the Grantham site, evidence of the frozen surface layer can be seen in Fig. 6a for TP1 and TP2. At these sites, a thick ice layer had to be chipped away in order to reach the soil surface while the other locations only had a snow cover. At depth, the DCP values for 22 March and 4 June are fairly similar (Fig. 6a, 6b). After the vehicle passage, little difference is seen in DCP values except for one of the test point 3 (TP3) measurements. This was not seen in the cone index measurements.

As mentioned in Section 4, different instruments were used to quantify soil strength at both sites. Which values to use for a given instrument was also investigated. The results of these comparisons are shown in Tables 2-4. It should be noted that the maximum CBR is capped at $100 \%$, equivalent to crushed rock. At both CEATS and Grantham, the winter measurements are much larger than the spring ones as can be seen in Tables 2 and 3. Also, Table 4 is for more than one testing date at Grantham. It is common practice to use the fourth drop with the Clegg impact hammers although, at times, the third one is used. Not much difference is seen between the CBR values generated using the $3^{\text {rd }}$ and $4^{\text {th }}$ IV values with the $2.25 \mathrm{~kg}$ Clegg as seen in Tables 2-4. There was a difference with the $4.5 \mathrm{~kg}$ Clegg especially on 26 February at CEATS where the $3^{\text {rd }}$ drop CBR values were much smaller than the $4^{\text {th }}$ drop CBR. The $4^{\text {th }}$ IV CBR results for the $4.5 \mathrm{~kg}$ Clegg were more aligned with the $2.25 \mathrm{~kg}$ ones on 26 February while on 22 March at Grantham, both were substantially higher. The $0.5 \mathrm{~kg}$ hammer was too light to use at CEATS, but we were able to use it at Grantham on 22 March before it broke. In general, the CBR values calculated using the $0.5 \mathrm{~kg}$ hammer were on the order of those determined using the $2.25 \mathrm{~kg}$ one as shown in Table 3. 

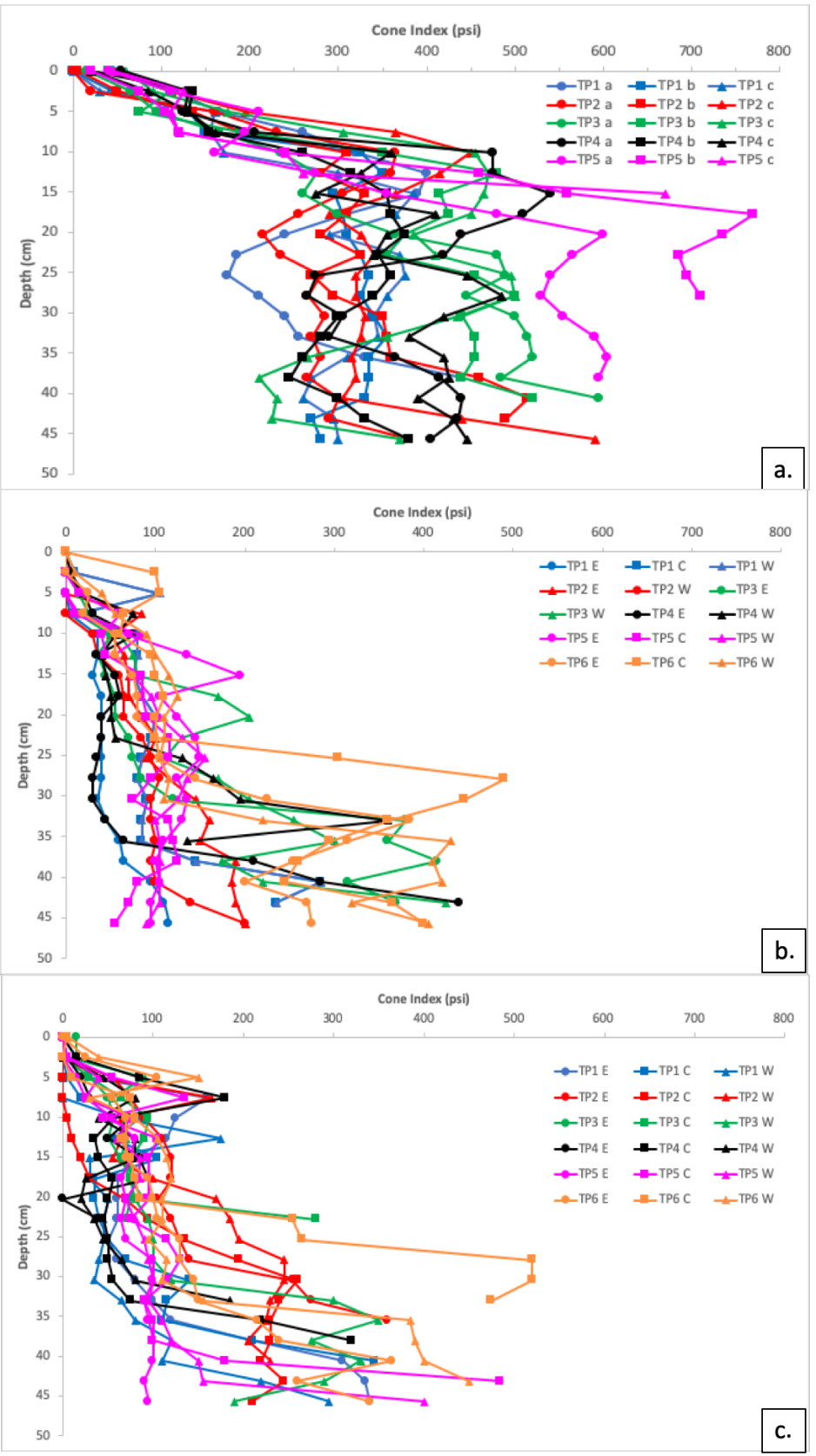

Fig. 4. Cone index profiles. a. 16 April at CEATS, b. 4 June at Grantham before vehicle passage, c. 6 June at Grantham after vehicle passage.

As stated previously, the cone penetrometer could not be used during the winter testing at either site due to the hardness of the surface layer. It could be used for spring testing. On 16 April at CEATS, the CBR values calculated using Eqn. 2 are much higher than either the Clegg or DCP measurements for both the SM and MH soils. This is not true with the 4 and 6 June calculations at Grantham. At this time, it is unknown what is causing the differences. 


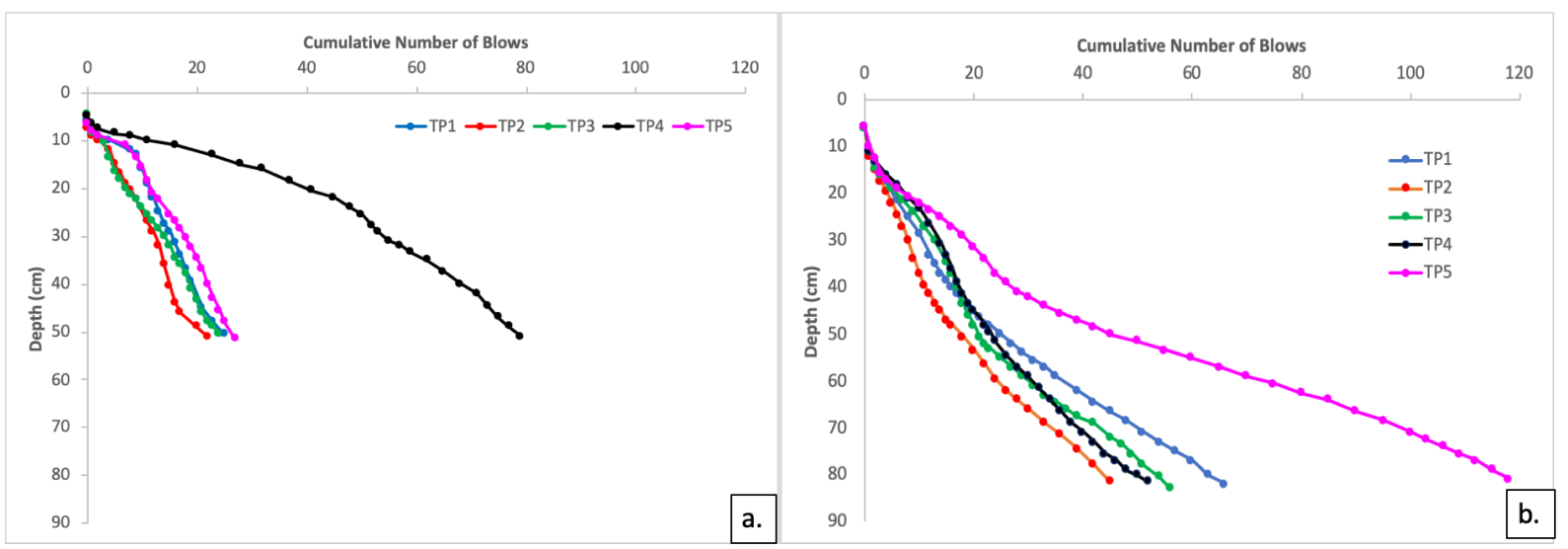

Fig. 5. DCP at CEATS. a. 26 February, b. 16 April.

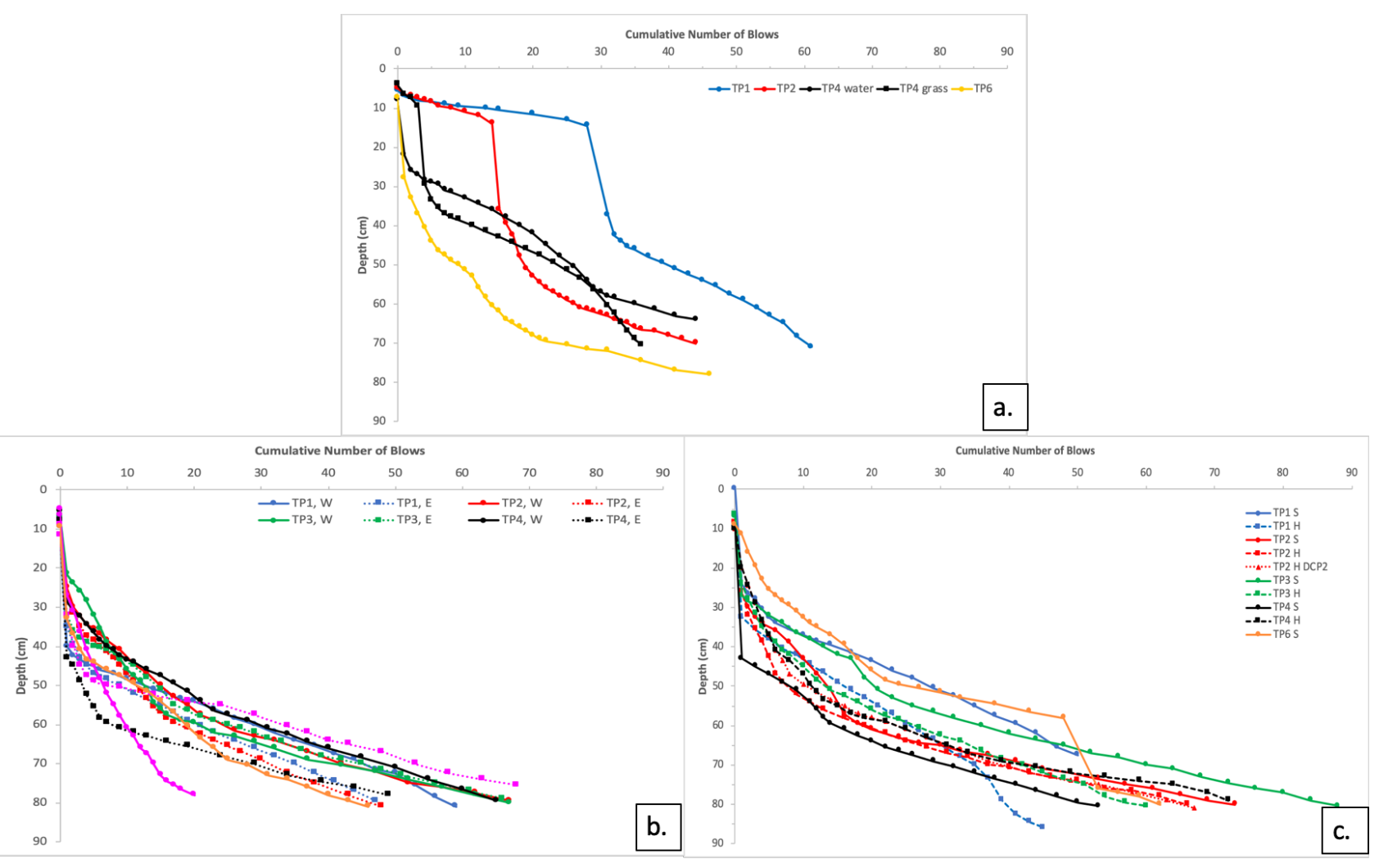

Fig. 6. DCP at Grantham. a. 22 March, b. 4 June, c. 6 June.

Based on Wieder et al. (2018), the DCP CBR measurements are reported as the total depth average unless layering is noted. Since NRMM uses the strength of the $0-15 \mathrm{~cm}$ and $15-30 \mathrm{~cm}$ layers, the average CBR in the upper $0-15 \mathrm{~cm}$ and $0-30 \mathrm{~cm}$ were investigated as well as the total depth averaged value as shown in Table 2 . In winter, the $0-15 \mathrm{~cm}$ layer is the strongest while in spring it is the weakest as was expected. Also, in winter at CEATS, the soil strength is more homogeneous with depth than in spring. Due to the nature of the soil at Grantham it was only possible at most test locations to report the total depth averaged DCP values. During the winter testing at Grantham (Table 3) the DCP values are much more scattered than the Clegg measurements. In Tables 3 and 4 the DCP water measurements at TP3 were taken in standing water. Even though there is some scatter in the various strength measurements on 4 and 6 June before and after vehicle passage, the values are too low to make a statement about specific trends. 
Table 2. CBR (\%) values for CEATS on 26 February and 16 April 2019 for various instruments.

\begin{tabular}{|c|c|c|c|c|c|c|c|c|c|c|}
\hline \multirow{2}{*}{ Method } & \multicolumn{2}{|c|}{ TP1 } & \multicolumn{2}{c|}{ TP2 } & \multicolumn{2}{c|}{ TP3 } & \multicolumn{3}{c|}{ TP4 } & \multicolumn{3}{|c|}{ TP5 } \\
\cline { 2 - 11 } & 26 Feb & 16 Apr & 26 Feb & 16 Apr & 26 Feb & 16 Apr & 26 Feb & 16 Apr & 26 Feb & 16 Apr \\
\hline $\begin{array}{c}2.25 \mathrm{~kg} \text { Clegg } \\
3^{\text {rd }} \text { IV }\end{array}$ & 8.5 & 1.2 & 8.3 & 1.2 & 13.0 & 1.2 & 100 & 1.1 & 83.7 & 1.4 \\
\hline $\begin{array}{c}2.25 \mathrm{~kg} \text { Clegg } \\
4^{\text {th }} \text { IV }\end{array}$ & 8.5 & 1.4 & 8.8 & 1.1 & 11.6 & 1.3 & 100 & 1.2 & 100 & 1.4 \\
\hline $\begin{array}{c}4.5 \mathrm{~kg} \text { Clegg } \\
3^{\text {rd }} \text { IV }\end{array}$ & 3.0 & & & & & & 3.0 & & 3.0 & \\
\hline $\begin{array}{c}4.5 \mathrm{~kg} \text { Clegg } \\
4^{\text {th }} \text { IV }\end{array}$ & 23.4 & & 15.0 & & & & 83.9 & & 39.4 & \\
\hline $\begin{array}{c}\text { DCP } \\
0-15 \mathrm{~cm}\end{array}$ & 8.9 & 2.1 & 5.9 & 1.9 & 4.1 & 2.0 & 20.9 & 2.3 & 8.1 & 5.8 \\
\hline $\begin{array}{c}\text { DCP } \\
0-30 \mathrm{~cm}\end{array}$ & 4.6 & 3.5 & 5.2 & 3.0 & 5.2 & 4.4 & 18.2 & 4.6 & 5.9 & 6.0 \\
\hline $\begin{array}{c}\text { DCP } \\
\text { total depth }\end{array}$ & 4.3 & 7.2 & 4.2 & 4.7 & 4.9 & 6.0 & 15.0 & 5.9 & 4.8 & 11.8 \\
\hline $\begin{array}{c}\text { Cone Pen } \\
0-15 \mathrm{~cm}, \mathrm{SM}\end{array}$ & & 15.7 & & 16.0 & & 15.3 & & 15.2 & & 13.7 \\
\hline $\begin{array}{c}\text { Cone Pen } \\
0-15 \mathrm{~cm}, \mathrm{MH}\end{array}$ & & 3.8 & & 3.9 & & 3.7 & & 3.6 & & 3.1 \\
\hline
\end{tabular}

Table 3. CBR (\%) values for Grantham on 22 March for various instruments.

\begin{tabular}{|c|l|l|l|l|}
\hline Method & TP1 & TP2 & TP3 & TP4 \\
\hline $2.25 \mathrm{~kg}$ Clegg, $3^{\text {rd }}$ IV & 21.6 & 16.0 & 6.8 & 8.7 \\
\hline $2.25 \mathrm{~kg}$ Clegg, $4^{\text {th }}$ IV & 35.5 & 20.0 & 6.3 & 21.2 \\
\hline $4.5 \mathrm{~kg}$ Clegg, $3^{\text {rd }}$ IV & 100 & 83.6 & & \\
\hline $4.5 \mathrm{~kg}$ Clegg, $4^{\text {th }}$ IV & 100 & 100 & & \\
\hline $0.5 \mathrm{~kg} \mathrm{Clegg,} 4^{\text {th }} \mathrm{IV}$ & 3.0 & 29.4 & & 29.4 \\
\hline DCP, $0-30 \mathrm{~cm}$ & 48.8 & 18.9 & $0.2 / 0.7$ & 0.02 \\
\hline
\end{tabular}

Table 4. CBR (\%) values for Grantham on 22 March, 16 April, 4 and 6 June for the DCP and cone penetrometer.

\begin{tabular}{|c|l|c|c|c|c|}
\hline \multicolumn{2}{|c|}{ Location and Method } & 22 March & 23 April & 4 June & 6 June \\
\hline \multirow{4}{*}{ TP0 } & DCP, total depth & & & & \\
\cline { 2 - 6 } & Cone Pen, 0-13 cm & & 1.9 & & \\
\cline { 2 - 6 } & Cone Pen, 0-15 cm & & 1.9 & & \\
\hline \multirow{4}{*}{ TP1 } & DCP, total depth & 6.5 & & 2.0 & 1.8 \\
\cline { 2 - 6 } & Cone Pen, 0-13 cm & & 2.2 & 1.9 & 2.5 \\
\hline & Cone Pen, 0-15 cm & & 2.2 & 1.9 & 2.4 \\
\hline \multirow{4}{*}{ TP2 } & DCP, total depth & 3.0 & & 2.2 & 2.7 \\
\cline { 2 - 6 } & Cone Pen, 0-13 cm & & 2.6 & 2.2 & 2.3 \\
\hline & Cone Pen, 0-15 cm & & 2.8 & 2.2 & 2.5 \\
\hline \multirow{4}{*}{ TP4 } & DCP, total depth & $1.8 / 3.4$ & & 2.6 & 3.7 \\
\cline { 2 - 6 } & Cone Pen, 0-13 cm & & 2.4 & 2.2 & 2.0 \\
\cline { 2 - 6 } & Cone Pen, 0-15 cm & & 2.5 & 2.3 & 2.1 \\
\cline { 2 - 6 } & DCP, total depth & 1.7 & & 1.8 & 3.6 \\
\hline & Cone Pen, 0-13 cm & & 2.4 & 1.9 & 2.4 \\
\hline \multirow{3}{*}{ TP5 } & Cone Pen, 0-15 cm & & 2.3 & 2.0 & 2.4 \\
\cline { 2 - 6 } & DCP, total depth & & & 1.2 & 2.2 \\
\cline { 2 - 6 } & Cone Pen, 0-13 cm & & 2.9 & 2.1 & 2.0 \\
\cline { 2 - 6 } & Cone Pen, 0-15 cm & & 3.0 & 2.2 & 2.1 \\
\hline
\end{tabular}




\begin{tabular}{|c|l|l|l|l|l|}
\hline \multirow{4}{*}{ TP6 } & DCP, total depth & & & & 2.9 \\
\cline { 2 - 5 } & Cone Pen, 0-13 cm & & 2.0 & 2.3 & 2.4 \\
\cline { 2 - 5 } & Cone Pen, 0-15 cm & 2.1 & 2.4 & 2.5 \\
\hline
\end{tabular}

\subsection{Soil Moisture}

As mentioned previously, soil moisture was measured using the buried probes, TDR, and eGauge. Since the $12 \mathrm{~cm}(4.8$ in) tines were used for the TDR, comparison was made of the top two (eGuage 0-10 $\mathrm{cm}$ ) and top three (eGuage 0-15 $\mathrm{cm})$ eGuage values. At both Grantham and CEATS, the eGauge measurements were lower than the other two techniques as can be seen in Tables 5 and 7 while there is good agreement between the TDR and buried probe measurements. No differences were observed between averaging over the top $5 \mathrm{~cm}$ (buried $0-5 \mathrm{~cm}$ ) and $10 \mathrm{~cm}$ (buried $0-10 \mathrm{~cm}$ ) buried probes as shown in Tables 5 and 7. In Tables 5 the 22 March values are considerably lower than the April and June measurements. This is due to the fact that the soil was frozen. Despite this, residual soil moisture could be measured with both the buried probes and the eGauge. No measurements were made using the TDR as the soil was too hard to insert the tines.

Little difference in soil moisture is seen before (4 June) and after (6 and 10 June) vehicle testing at Grantham (Table 6) even though standing water was observed in the ruts. The exception to this is TP3 on 10 June. In the HMMWV drawbar pull tests which were performed slightly up-hill (east) of the other tests at Grantham on the south side of the barns (Fig. 2a) more traction was measured at TP3 than at TP2 or TP1 (Parker et al., 2019 this issue). It was thought that this could be attributed to soil moisture differences since TP3 is slightly higher, and hence, slightly drier than the lower TP3 test sites. It is not however, drier than the other two sites measured on the HMMWV drawbar pull tracks and so is not the cause for the differences. The presence of surface water could be a factor. Standing water was observed at TP1 and less so at TP2 while at TP3 the surface was dry.

Also notable in Tables 5-7 that CEATS is significantly drier than Grantham. The eastern most test site (TP5) at CEATS is slightly drier than the other test points (Table 5). It is also slightly higher. At Grantham many of the test locations had standing water in old tractor ruts. Test locations three (TP3), four (TP4) and six (TP6) were wetter than the other locations even though visually no difference was observed. The plant species was different at these locations and this could be the cause for the wetter soil as the plants are not absorbing as much water. This is still under investigation.

Table 5. Soil moisture values for all instruments at CEATS on 16 April 2019.

\begin{tabular}{|c|c|c|c|c|c|c|c|c|c|c|c|c|c|c|c|}
\hline \multirow{2}{*}{ Method } & \multicolumn{3}{|c|}{ TP1 } & \multicolumn{3}{|c|}{ TP2 } & \multicolumn{3}{|c|}{ TP3 } & \multicolumn{3}{|c|}{ TP4 } & \multicolumn{3}{|c|}{ TP5 } \\
\cline { 2 - 14 } & Ave & Min & Max & Ave & Min & Max & Ave & Min & Max & Ave & Min & Max & Ave & Min & Max \\
\hline $\begin{array}{c}\text { TDR } \\
0-13 \mathrm{~cm}\end{array}$ & 41.8 & 40.2 & 42.7 & 47.1 & 44.2 & 49.9 & 42.2 & 39.8 & 44.2 & 45.0 & 43.8 & 45.6 & 41.1 & 38.7 & 42.7 \\
\hline $\begin{array}{c}\text { eGauge } \\
0-10 \mathrm{~cm}\end{array}$ & 31.0 & 30.9 & 31.0 & 30.5 & 30.5 & 30.6 & 30.9 & 30.9 & 30.9 & 30.9 & 30.9 & 30.9 & 23.3 & 23.3 & 23.3 \\
\hline $\begin{array}{c}\text { eGauge } \\
0-15 \mathrm{~cm}\end{array}$ & 31.0 & 30.9 & 31.0 & 30.5 & 30.4 & 30.6 & 30.9 & 30.9 & 30.9 & 31.0 & 30.9 & 31.1 & 23.3 & 23.3 & 23.4 \\
\hline $\begin{array}{c}\text { Buried } \\
0-5 \mathrm{~cm}\end{array}$ & 43.6 & 41.3 & 46.0 & & & & & & & & & & & & \\
\hline $\begin{array}{c}\text { Buried } \\
0-10 \mathrm{~cm}\end{array}$ & 45.1 & 41.3 & 48.0 & & & & & & & & & & & & \\
\hline
\end{tabular}

Table 6. Soil moisture values from the TDR at Grantham for all June 2019 measurements.

\begin{tabular}{|c|c|c|c|c|c|c|c|c|c|c|c|c|c|c|c|c|c|c|}
\hline \multirow{2}{*}{ Date } & \multicolumn{3}{|c|}{ TP1 } & \multicolumn{3}{|c|}{ TP2 } & \multicolumn{3}{|c|}{ TP3 } & \multicolumn{3}{|c|}{ TP4 } & \multicolumn{3}{|c|}{ TP5 } & \multicolumn{3}{|c|}{ TP6 } \\
\hline & Ave & Min & Max & Ave & Min & Max & Ave & Min & Max & Ave & Min & Max & Ave & Min & Max & Ave & Min & Max \\
\hline $\begin{array}{c}4 \\
\text { June }\end{array}$ & 72.3 & 69.8 & 74.5 & 67.6 & 62.6 & 71.6 & 87.3 & 83.2 & 91.5 & 77.9 & 73.1 & 87.2 & 69.6 & 47.8 & 74.9 & & & \\
\hline $\begin{array}{c}6 \\
\text { June }\end{array}$ & 72.0 & 68.4 & 73.8 & 69.3 & 65.9 & 72.4 & 87.3 & 79.6 & 93.3 & 85.2 & 75.3 & 96.6 & 72.8 & 70.2 & 74.2 & 89.1 & 72.7 & 109.6 \\
\hline $\begin{array}{c}10 \\
\text { June }\end{array}$ & 70.3 & 68.0 & 73.4 & 69.9 & 66.2 & 72.7 & 74.4 & 56.5 & 87.9 & & & & & & & & & \\
\hline
\end{tabular}


Table 7. Soil moisture values at TP2 for all instruments at Grantham on all testing dates.

\begin{tabular}{|c|c|c|c|c|c|c|c|c|c|c|c|c|c|c|c|}
\hline \multirow{2}{*}{ Method } & \multicolumn{3}{|c|}{$22 \mathrm{March}$} & \multicolumn{3}{|c|}{9 April } & \multicolumn{3}{|c|}{23 April } & \multicolumn{3}{|c|}{4 June } & \multicolumn{3}{|c|}{6 June } \\
\hline & Ave & Min & Max & Ave & Min & Max & Ave & Min & Max & Ave & Min & Max & Ave & Min & Max \\
\hline $\begin{array}{c}\text { TDR } \\
0-13 \mathrm{~cm} \\
\end{array}$ & & & & 68.8 & 64.0 & 72.9 & 64.8 & 61.5 & 66.9 & 67.6 & 62.6 & 71.6 & 69.3 & 65.9 & 72.4 \\
\hline $\begin{array}{l}\text { eGauge } \\
0-10 \mathrm{~cm}\end{array}$ & 19.3 & 17.5 & 21.1 & & & & & & & 40.3 & 40.3 & 40.3 & 46.0 & 45.7 & 46.2 \\
\hline $\begin{array}{l}\text { eGauge } \\
0-15 \mathrm{~cm}\end{array}$ & 18.3 & 16.1 & 21.1 & & & & & & & 40.3 & 40.3 & 40.3 & 46.0 & 45.7 & 46.2 \\
\hline $\begin{array}{l}\text { Buried } \\
0-5 \mathrm{~cm}\end{array}$ & 9.7 & 9.5 & 9.9 & 69.9 & 69.2 & 70.6 & 73.4 & 68.4 & 78.4 & 62.8 & 58.9 & 65.8 & 65.7 & 57.2 & 71.6 \\
\hline $\begin{array}{c}\text { Buried } \\
0-10 \mathrm{~cm}\end{array}$ & 10.0 & 9.5 & 10.6 & 59.3 & 38.2 & 70.6 & 69.1 & 60.4 & 78.4 & 62.2 & 58.9 & 65.8 & 65.7 & 57.2 & 71.6 \\
\hline
\end{tabular}

\subsection{Soils Density}

In-situ density measurements were made at both CEATS and Grantham during vehicle testing using the eGauge. At CEATS, density was only measured before vehicle passage (Fig. 7a) while at Grantham, values were captured before (4 June, solid lines) and after (6 June, dotted lines) the SUSV and HMMWV tests as is shown in Fig. 7b. At CEATS, the density is similar at depth for all but the eastern most site (TP5, Fig. 7a). Here the soil was the densest although it visually didn't appear any different than the other test locations.

At Grantham little, if no, difference in surface density is seen before and after vehicle passage as can be in Fig. $7 \mathrm{~b}$. This could be due to the soil rebound that was observed and expected due to the elasticity of the root mass. At depth however, after vehicle testing the soil is less dense than before except at test location 3 (TP3, green lines). Prior to vehicle testing, a sample was taken for density measurement in the laboratory. No difference was seen between the laboratory and the in-situ density values.

\section{Conclusions}

Little to no engineering or vehicle mobility data exists for organic or peat soils types yet these soils are very common and important for vehicle operations in northern environments. Therefore, a research study was initiated to quantify trafficability of both light-weight wheeled and tracked vehicles on these soils seasonally. These tests are the first of a series of experiments to investigate effects of different organic soil types on mobility on a seasonal basis.

Further tests need to be carried out in other seasonal settings and in different peat soils before more definitive conclusions can be reached. To this extent, tests at CEATS and Grantham are planned for drier conditions and tests are also planned in Estonia in the Fall of 2019. The peat soils in Estonia are, in general, more competent and thicker. It will again be difficult to separate the effects of vegetation from the organic soils. Different vehicles will also be used besides the SUSV and HMMWV used for these studies. Finally, laboratory tests are needed to fill in data not collected in the field.

\section{Nomenclature}

$\begin{array}{lll}\text { CBR } & \text { California Bearing Ratio } & {[\%]} \\ \text { CI } & \text { Cone Index } & {[\mathrm{kPa}]} \\ \text { DCP } & \text { Dynamic Cone Penetrometer } & {[\mathrm{mm} / \mathrm{blow}]} \\ \text { IV } & \text { Impact Value } & \\ \text { UCSC } & \text { Unified Soil Classification System } & \end{array}$




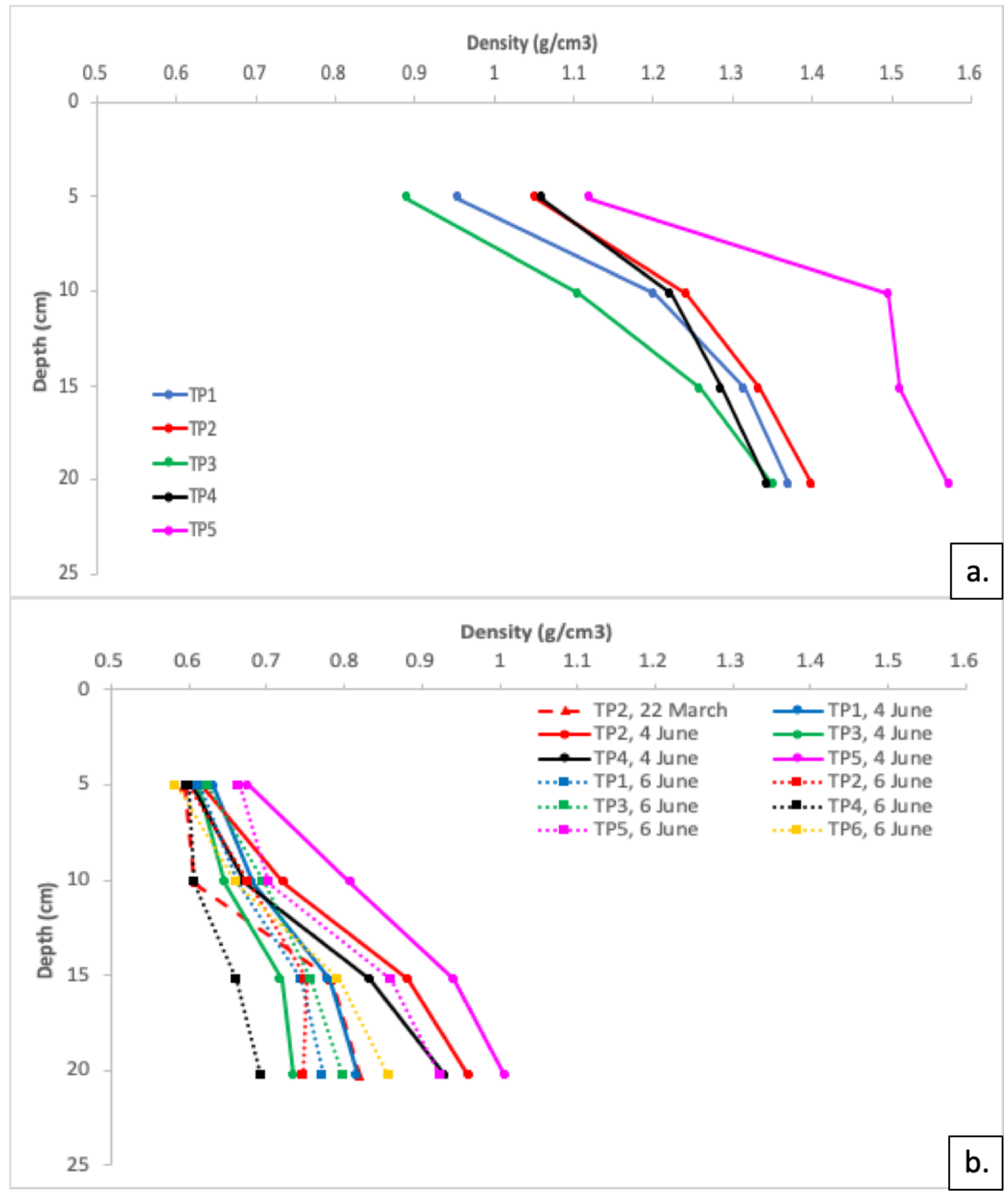

Fig. 7. Soil Density. a. CEATS, b. Grantham.

\section{Acknowledgements}

Funding for this effort was provided by the Mobility in Peat and Northern Soils project under the 6.2 T40 ASTMIS Task \#48: Entry and Sustainment in Complex Contested Environments work package. 


\section{References}

Affleck, R.T., Ryerson, C.C., Barna, L.A., Claffey, K.J., 2008. Suitability Measurements and Analysis for El Centro Naval Air Facility OLS. ERDC/CRREL TR-08-18. Hanover, NH. Air Force, 2002.

Airfield pavement evaluation standards and procedures. AFCESA/CES Engineering Technical Letter 02-19. Tyndall Air Force Base, FL.

ASTM, 2018. Standard Test Method for In-Place Bulk Density of Soil and Soil-Aggregate by a Low-Activity Nuclear Method (Shallow Depth). Designation: D8167-18a. West Conshohocken, PA.

Clegg, B.W.D., 1986. Clegg Impact Soil Tester (The Clegg Hammer). Newsletter No. 2, rev. 11/11/11. 2/23 Bishop St, Jolimont, Western Australia.

HQ Army and Airforce, 1994. Planning and design of roads, airfields, and heliports in the theater of operations - road design. FM 5-430-00-1/AFJPAM 32-8013, Vol. 1. Washington DC.

Parker, M., Stott, A., Bodie, M., Frankenstein, S., Shoop, S., 2019. Vehicle Mobility on Highly Organic Soils. Proceedings ISTVS $15^{\text {th }}$ European-African Regional Conference, Prague, Czech Republic.

Radforth, N., Rush, E., 1961. Trafficability Tests on Confined Organic Terrain (Muskeg). Report 1: Summer 1961. Tests. Technical Report, No.3-656. Vicksburg, MS.

Richmond, P. W., Shoop, S. A., Blaisdell, G. L., 1995. Cold Regions Mobility Models. CRREL Report 95-1. Hanover, NH. http://hdl.handle.net/11681/9179.

SDi, 2000. Clegg impact soil tester, operators manual. Trowbridge, Wilshire, UK: Simon Deakin Instrumentation.

Shoop, S., 1995. Vehicle Bearing Capacity of Frozen Ground over a Soft Substrate. Canadian Geotechnical Journal 32:552-556.

Shoop, S.A., Diemand, D., Wieder, W.L., Mason, G., Seman, P.M., 2008. Predicting California bearing ratio from trafficability cone index values. ERDC/CRREL Technical Report TR-08-17. Hanover, NH.

Troxler, 2015. eGauge Model 4590 Surface Density Gauge, Manual of Operation and Instruction. Troxler Electronic Laboratories, Inc. Research Triangle Park, NC.

Vennik, K., Keller, T., Kukk, P., Krebstein, K., Reintam, E., 2017. Soil rut depth prediction based on soil strength measurements on typical Estonian soils. Biosystems Engineering 163: 78-86.

Webster, S.L., Grau, R.H., Williams, T.P., 1992. Description and Application of Dual Mass Dynamic Cone Penetrometer. USACE WES Instruction Report GL-92-3.

Wieder, W., Shoop, S., Barna, L., Franz, T., Finkenbiner, C., 2018. Comparison of soil strength measurements of agricultural soils in Nebraska. Journal of Terramechanics 77: 31-48.

Wong, J., Garber, M., Radforth, J., Dowell, J., 1979. Characterization of the Mechanical Properties of Muskeg with Special Reference to Vehicle Mobility. Journal of Terramechanics 16 (4): 163-180.

Wong, J., Radforth, J., Preston-Thomas, J., 1982. Some Further Studies on the Mechanical Properties of Muskeg in Relation to Vehicle Mobility. Journal of Terramechanics 19 (2): 107-127. 


\section{REPORT DOCUMENTATION PAGE}

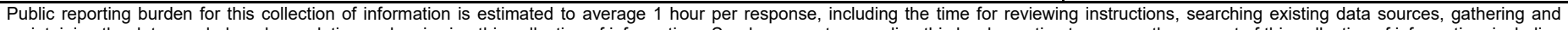

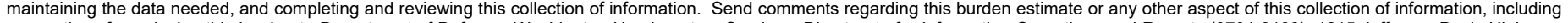

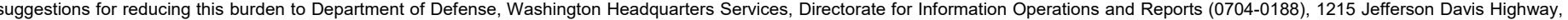

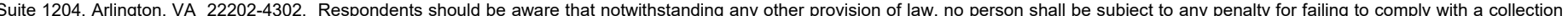
of information if it does not display a currently valid OMB control number. PLEASE DO NOT RETURN YOUR FORM TO THE ABOVE ADDRESS.

\begin{tabular}{|l|l|l|}
$\begin{array}{l}\text { of information if it does not display a currently valid OMB control number. PLEASE DO NOT RETURN YOUR FORM TO THE ABOVE ADP } \\
\text { 1. REPORT DATE }\end{array}$ & $\begin{array}{c}\text { 2. REPORT TYPE } \\
\text { Final }\end{array}$ \\
\hline
\end{tabular}

\section{TITLE AND SUBTITLE}

Peat and Organic Soil Characterization During Seasonal Mobility Testing

3. DATES COVERED (From - To)

5a. CONTRACT NUMBER

5b. GRANT NUMBER

5c. PROGRAM ELEMENT NUMBER 62784

6. AUTHOR(S)

Susan Frankenstein, Lynette Barna, Bruce Elder, Sally Shoop, Mike Parker, Michelle Michaels, and Mary Feyrer

5d. PROJECT NUMBER

AT40

5e. TASK NUMBER

48

5f. WORK UNIT NUMBER

7. PERFORMING ORGANIZATION NAME(S) AND ADDRESS(ES)

U.S. Army Engineer Research and Development Center

Cold Regions Research Laboratory

8. PERFORMING ORGANIZATION REPORT NUMBER

72 Lyme Road

Hanover, NH 03755

ERDC/CRREL MP-20-7

9. SPONSORING / MONITORING AGENCY NAME(S) AND ADDRESS(ES)

Assistant Secretary of the Army for Acquisitions, Logistics \& Technology

103 Pentagon

Washington, DC 20314-1000

10. SPONSOR/MONITOR'S ACRONYM(S)

11. SPONSOR/MONITOR'S REPORT NUMBER(S)

\section{DISTRIBUTION / AVAILABILITY STATEMENT}

Approved for public release; distribution is unlimited.

\section{SUPPLEMENTARY NOTES}

Originally published in Proceedings of the ISTVS 15th European-African Regional Conference, Prague, Czech Republic, September 9-11, 2019.

\section{ABSTRACT}

Renewed interest in cross country mobility due to the current global political climate, as well as greater accessibility to northern regions due to climate change, has led to identification of deficiencies in current mobility modeling capabilities on peat and organic soils for both tracked and wheeled vehicles. As a result, field tests at two locations were initiated in the Winter of 2019 to quantify vehicle, soil, and other environmental characteristics. Measured parameters include, but are not limited to, soil moisture and temperature profiles from the surface to $50 \mathrm{~cm}$ depth; full weather forcing variables; snow depth; soil characterization including grain size distribution, density, porosity, organic content, and inherent strength factors; vegetation type and density including root structure; soil strength; vehicle traction, resistance, and sinkage. Tests are designed to capture seasonal conditions to include frozen soil, early thaw, and mid-summer. Preliminary analysis of the soil and environmental characteristics are presented in this paper.

\section{SUBJECT TERMS}

Peat, Field Experiments, Vehicle Mobility, Frozen Ground, Organic

\begin{tabular}{|c|c|c|c|c|c|}
\hline \multicolumn{3}{|c|}{ 16. SECURITY CLASSIFICATION OF: } & \multirow{2}{*}{$\begin{array}{c}\text { 17. LIMITATION } \\
\text { OF ABSTRACT } \\
\text { SAR }\end{array}$} & \multirow{2}{*}{$\begin{array}{l}\text { 18. NUMBER } \\
\text { OF PAGES } \\
\qquad 17\end{array}$} & \multirow{2}{*}{$\begin{array}{l}\text { 19a. NAME OF RESPONSIBLE } \\
\text { PERSON } \\
\begin{array}{l}\text { 19b. TELEPHONE NUMBER (include } \\
\text { area code) }\end{array}\end{array}$} \\
\hline $\begin{array}{l}\text { a. REPORT } \\
\text { Unclassified }\end{array}$ & $\begin{array}{l}\text { b. ABSTRACT } \\
\text { Unclassified }\end{array}$ & $\begin{array}{l}\text { c. THIS PAGE } \\
\text { Unclassified }\end{array}$ & & & \\
\hline
\end{tabular}

